\title{
TWO NEW MARINE SPECIES OF GYMNODINIUM ISOLATED FROM THE PLYMOUTH AREA
}

\author{
By Dorothy Ballantine
}

The Plymouth Laboratory

(Text-figs. I-I 7)

The two new species, Gymnodinium vitiligo and $G$. veneficum, which are described below, are both small and highly motile, and in other respects very similar. The greatest difference between them is physiological, as $G$. vitiligo is harmless, whereas $G$. veneficum produces a very powerful toxin which is lethal to fish. There are also small morphological differences which are visible when the organisms are in culture, confirming the existence of two separate species.

I wish to thank Dr Mary Parke of this Laboratory for giving me these two organisms which she isolated, and for her unfailing help and advice, and Dr J. E. Morton, of Queen Mary College, for translating the English diagnoses into Latin.

\section{Diagnosis}

\section{SPECIFIC DESCRIPTIONS}

\section{Gymnodinium vitiligo n.sp. (Figs. I-5)}

Cells broadly oval, small, not flattened. Epicone slightly smaller than the hypocone, cell rounded at the apex and antapex. Girdle deeply impressed, narrower on the ventral side, displaced about two girdle widths. Anterior pore at the junction of the left side of the girdle and sulcus, posterior pore at the junction of the right side of the girdle and sulcus. Sulcus extends on to epicone and hypocone, deeply impressed at the junction with the girdle and gradually decreasing in depth towards apex and antapex. Transverse flagellum extending all around the body, longitudinal flagellum very fine, $\mathrm{I}-\mathrm{I} \frac{1}{4}$ times the cell length. The right ventral side of the epicone is produced into a hooklike flap which protrudes and overlaps the girdle and sulcus to some extent. Nucleus median, indistinct except just prior to cell division. Cytoplasm hyaline, containing refractile oily bodies. Periplast rigid, but without apparent structure, cell slightly metabolic. Chromatophores golden brown, irregular in shape, usually four (varying from 2 to 8 and occasionally more). Cell size 7 -I $8 \mu \times 7-\mathrm{I} 4 \mu$, most common size II $5 \times 9 \cdot 5 \mu$. Not toxic to fish or other animals. 
Isolated by Dr Mary Parke from a sample of sea water from 4 fathoms from the Knap Buoy region off Plymouth Sound (lat. N. $50^{\circ}$ I9' $30^{\prime \prime}$, long. W. $04^{\circ} \mathrm{IO} 0^{\prime}$ ) on 8 June I949. Type culture (Plymouth collection no. I02) at the Marine Biological Assocation, Plymouth.

Cellula late ovata, parva, non planata, rotundata ad extremitates apicalem et antapicalem; parte epiconica parum minore quam hypoconica. Cingulo profunde impresso, angustiore ad aspectum ventralem, summoto fere bis suum latitudinem. Foraminibus ad conjunctionem utriusque partis cinguli cum sulco, anteriore sinistrae, posteriore dextrae. Sulco extendente in partem epiconicam necnon hypoconicam, profunde impresso ad conjunctionem cingulo, paulatim altitudine decrescente ut accedit ad extremitates apicalem et antapicalem. Altero flagello transverso totam cellulam circumstante, altero longitudinali tenuissimo, longiore I-I.25 quam cellula. Dextro latere partis epiconicae producto ex aspectu ventrali in processum fere hamuliformem sed et rotundatum qui super cingulum sulcumque nonnullomodo extendit. Nucleo medio, inconspicuo nisi ante fissionem cellulae. Cytoplasmate hyalino, abundante corporibus oleacibus refractilibus; periplasto rigido, clara structura defecta; cellulae forma paulum mutante; chromatophoris aureo-brunneis, forma irregularibus, ex norma 4 (numero variantibus $2-8$, nonnunquam pluribus). Cellulae magnitudine $7-\mathrm{I} 8 \mu \times 7-\mathrm{I} 4 \mu$, plerumque II.5 $\times 9 \cdot 5 \mu$. Non toxica piscibus et ceteris animalibus.

Isolata a Maria Parke exemplo aquae marinae ad regionem Knap Buoy prope Plymouth Sound, profound. c. 8 metr., 8 jun. 1949. Cultura typica conservata (Collectio Plymouth num. I02) ad laboratorium Marine Biological Association, Plymouth.

\section{Diagnosis Gymnodinium veneficum n.sp. (Figs. 6-I7)}

Cell ovoid, small, not flattened. Epicone and hypocone equal, but epicone more pointed. Girdle deeply impressed, displaced about one girdle width. Anterior pore at the junction of the left side of the girdle and sulcus, posterior pore at the junction of the right side of the girdle and sulcus. Sulcus extends on to the epicone and to the antapex, not deeply impressed, gradually decreasing in depth towards the apex and antapex. Transverse flagellum extending all round body, longitudinal flagellum fine, $\mathrm{I} \frac{1}{2}$ times the cell length. Nucleus median, indistinct except just prior to cell division. Cytoplasm hyaline, containing numerous refractile oily bodies. Periplast rigid, but without apparent structure, cell slightly metabolic. Chromatophores golden brown, irregular in shape, varying in number from 2 to 8 , usually 4 . Cell size $9-\mathrm{I} 8 \times 7-\mathrm{I} 4 \mu$, most common size $\mathrm{I} 2 \times 9.5 \mu$. This species produces an exotoxin which is lethal to fish and other animals.

Isolated by Dr Mary Parke from a sea-water sample from the Hamoaze, over Rubble Bank, off King William Point, South Yard, Devonport (lat. N. $50^{\circ} 2 I^{\prime} 50^{\prime \prime}$, long. W. $04^{\circ}$ IO' $^{\prime} 5^{\prime \prime}$ ) on 23 June I950. Type culture (Plymouth collection no. I03) deposited with the Type Culture Collection, Cambridge, and the Marine Biological Association, Plymouth.

Cellula ovoidali, parva, non planata, partibus epiconica et hypoconica aequalibus, epiconica tamen acutiore; cingulo profunde impresso, summoto fere aeque latitudini 
suo. Foraminibus ad conjunctionem utriusque partis cinguli cum sulco, anteriore sinistrae, posteriore dextrae. Sulco extendente in partem epiconicam et ad extrem1tatem antapicalem, non profunde impresso, paulatim altitudine decrescente ut accedit ad extremitates apicalem et antapicalem. Altero flagello transverso totam cellulam circumstante, altero longitudinali et tenui, longiore $I \cdot 5$ quam cellula. Nucleo medio, inconspicuo nisi ante fissionem cellulae; cytoplasmate hyalino, abundante numerosis corporibus refractilibus oleacibus; periplasto rigido, clara structura defecta, cellulae forma paulum mutante. Chromatophoris aureo-brunneis, forma irregularibus, numerosis 2-8, ex norma 4. Cellulae magnitudine 9-I $8 \times 7-\mathrm{I} 4 \mu$, plerumque $\mathrm{I} 2 \times 9.5 \mu$ Cellula substantiam exotoxicam producente quaeletalis sicpiscibus et ceteris animalibus.

Isolata a Maria Parke exemplum aquae marinae ex Hamoaze, supra Rubble Bank, prope King William Point, South Yard, Devonport 23 jun. I950. Cultura typica deposita in collectionem culturarum typicarum Cantabrigiensem, sed et ad laboratorium Marine Biological Association, Plymouth (Collectio Plymouth num. I03).

\section{Description}

Owing to their similarity the two organisms are best treated together. The features they share in common are described first, and the small but critical differences between them can then be made clear.

Their obvious similarity extends beyond mere superficial resemblances. The absorption spectra of total pigments, obtained from methanol extracts in a Unicam spectrophotometer, are identical. Both show peaks at 444 and $673 \mathrm{~m} \mu$, with suggested peaks for pigments other than chlorophyll $a$ at 425-430, 460-470 and 620-630 $\mathrm{m} \mu$.

Reproduction is by fission in the motile state, and no encystment or sexual reproduction has been observed. Cell division is the same in both species and will be described later for $G$. veneficum. The process appears to take $2-3 \mathrm{~h}$ to complete. The final number of cells attained in culture in Erdschreiber in both species is about the same ( $c a .200,000$ cells per ml., exceptionally 500,000 cells per ml.). Colourless cells have been observed rarely in both species, but these appear to occur only in old cultures, and are produced when an organism divides leaving all the chromatophores in one individual (cf. Parke, Manton \& Clarke, I955, p. 592). These cells have not been seen undergoing another division and their rarity in cultures suggests that they die out. Ingestion has not been observed, though both species have been given a large variety of possible foods, both natural and artificial. The chromatophores are irregular in shape, usually plate- or ribbon-like and usually four in number. In old cultures, however, the chromatophores may split up giving an almost reticulate appearance.

These organisms move in a characteristic fashion. They swim forward in a jerky irregular spiral, usually with the ventral side downwards. Movement is quite rapid and the cell rotates from time to time. The transverse flagellum undulates rapidly in the girdle during movement and the longitudinal flagellum either vibrates rapidly (during active swimming) or remains almost still, trailing behind (sluggish movement). 


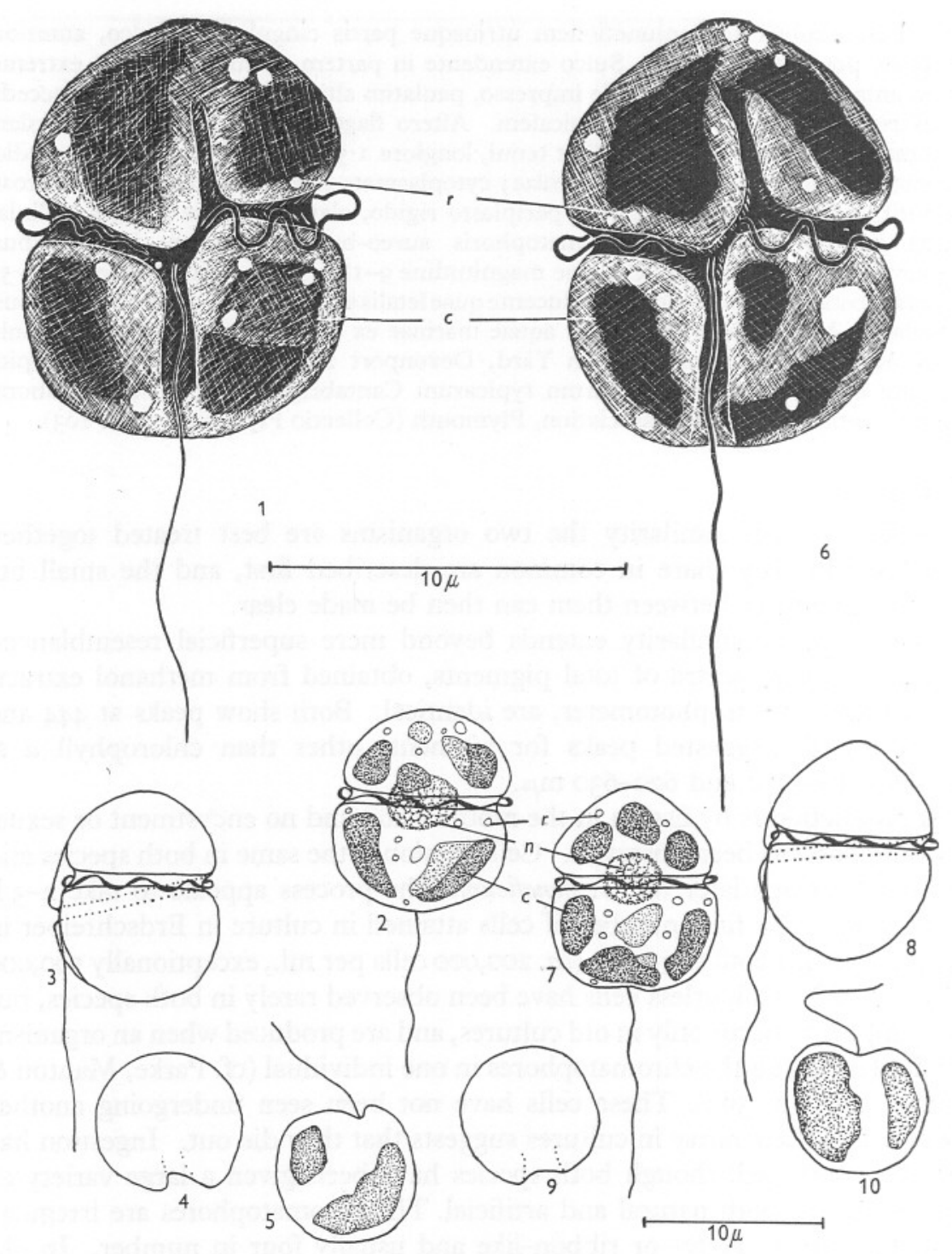

Figs. I-5. Gymnodinium vitiligo.

Fig. I. Ventral view. Fig. 2. Dorsal view. Fig. 3. View from the left side, showing the displacement of the girdle and projection of the right side of the epicone. Fig. 4. Apical view, showing sulcus. Fig. 5. Antapical view, showing sulcus and longitudinal flagellum.

Figs. 6-10. Gymnodinium veneficum.

Fig. 6. Ventral view. Fig. 7. Dorsal view. Fig. 8. View from the left side, showing displacement of the girdle. Fig. 9. Apical view, showing sulcus. Fig. I0. Antapical view, showing sulcus and longitudinal flagellum. $c$, chromatophore; $n$, nucleus; $r$, refractile bodies. 
Satisfactory fixation of these naked dinoflagellates has been found to be impossible. They lose shape or burst in many fixatives, and become absolutely unrecognizable in formalin. The greatest success has been obtained with the vapour from $4 \%$ osmic acid, but only small quantities of material can be fixed at one time, and even then many cells round off and throw off their flagella. This means that almost all observations have to be made on living material. Both vital staining and staining after osmic acid fixation have been used to try to determine the position of the nucleus and the composition of the refractile bodies present in both species. These bodies appear to be composed of a variety of substances. Starch appears to be formed in very small quantities by some, but not all, individuals in culture, as occasionally small scattered bodies staining blue-black with dilute iodine are observed. After prolonged contact with iodine the whole cell becomes brown. The remaining, usually very numerous, refractile bodies, which are scattered throughout the cytoplasm show up as orthochromatic granules, or vacuoles, absorbing cresyl blue and neutral red without altering the colour of the stain. They also stain with methylene blue and Nile blue. It is felt that these bodies have a lipid base, as osmic acid and Sudan black B both give a black stain. The periplast shows up with trypan blue or iodine staining, but no structure can be seen in either species. Gymnodinium vitiligo appears to have a firmer periplast than G. veneficum, as it stays a better shape on fixation and survives longer when examined living under the microscope.

In neither species has a pusule been observed, this being either lacking, or, possibly, obscured by the many other cell contents.

The characters which distinguish these two species are few, and undoubtedly the most important is the toxicity of $G$. veneficum. Whereas all marine animals so far tested have lived for days in $G$. vitiligo culture, fish are killed within a short time by G. veneficum (Io min for Gobius ruthensparri). This toxicity also affects molluscs, which die in a few hours, and to a lesser extent arthropods and echinoderms. This work will be discussed separately and more fully, in collaboration with $\mathrm{Dr}$ B. C. Abbott. The slow toxicity to animals other than fish has already been reported by Bainbridge (I953, p. 393 - Hemimysis lamornae), Marshall \& Orr (1955, p. 510-Calanus) and Ballantine \& Morton (1956, p. 246-Lasaea rubra).

The other distinguishing characters between the two species are morphological and can be seen by comparing the figures (I-IO). In general outline $G$. vitiligo is more rounded at the apex (Figs. I and 6), has a more deeply impressed sulcus (Figs. I, 4, 5 and 6, 9, 10) and more displaced girdle (Figs. $3,8)$ than $G$. veneficum. The greatest distinction between them under the microscope is the prominence of the hook-like right side of the epicone in G. vitiligo. This structure is at times very pronounced, and even if not very well developed shows up the girdle and sulcus very clearly when the cell is living. By contrast there is no protrusion in G. veneficum, and the sulcus and girdle 
are not so clearly defined, nor so deep. The shape of the sulcus also differs when seen in section, as in Figs. 4 and 5, 9 and Io. These views from the apex and antapex show the influence on the sulcus shape of the hook on the right side of the epicone and the less prominent outward development of the left side of the hypocone of $G$. vitiligo as compared with the almost equal development at each side of the sulcus in $G$. veneficum. In addition to these features the longitudinal flagellum of $G$. veneficum is longer and coarser.

With regard to the relationships of these two species within the genus, little can be said. The nearest species appear to be G. simplex (Lohmann) Kofoid \& Swezy, G. pygmaeum Lebour, G. marylandicum Thompson and G. mirum Ütermohl. G. brevis Davis (I948), which is also toxic, differs greatly morphologically, being lobed and flattened, and the remaining species listed all have quite marked distinguishing characters. G. simplex has a straight girdle, a sulcus that does not extend to the epicone (Lebour, 1925) and much smaller cells $(\mathrm{I} \cdot 7-7 \mu)$. The sulcus in G. pygmaeum Lebour (I925) extends over both apex and antapex and is overlapped on the left side by a tongue-like process, absent in the new species. The remaining two species are freshwater. In G. mirum Ütermohl ( $=G$. rotundatum Schiller non Klebs and G. obesum Schiller, I933, see Nygaard, 1949) the general shape is similar, but the girdle is straight or only very slightly displaced, the sulcus is very oblique on the epicone and the chromatophores are numerous and small. G. marylandicum Thompson (1947) somewhat resembles G. veneficum and G. vitiligo from the ventral aspect, but differs in being dorso-ventrally flattened. Thus apparently there are no very closely related species in the genus, which though large is very diverse.

\section{Notes on Cell Division}

Cell division was observed closely in both species, is the same in each, and has been illustrated for Gymnodinium veneficum (Figs. I I-I7). The first stage of division is observed as a doubling of the longitudinal flagellum and indentation of the antapex (Fig. II). Shortly after this stage the organism becomes somewhat quiescent. Indentation of the hypocone continues and the new transverse flagellum appears, one remaining in the girdle and the new flagellum free and undulating, usually directed towards the hypocone (Figs. I2, I3). When division of the cell has reached a point above the girdle the new transverse flagellum encircles the body and goes into position in the girdle (Fig. I4). Division of the epicone now proceeds from all directions, until only a thin connexion of cytoplasm is left (Fig. I5). Division of the nucleus is complete at this stage, but nuclear division has not been observed at all stages as the nucleus, though large and median in position, does not show clearly except just prior to division. It was found impossible after fixation to 
ascertain the stage to which division had proceeded, and thus alcoholic stains could not be used. Normally there are four chromatophores, but an early stage after division may contain only two, which later divide. The chromatophores may also divide prior to, or during, cell division, and organisms giving the appearance of Fig. I5 are not uncommon. The joined individuals are by now again rotating rapidly and irregularly, and during this gyration they pivot
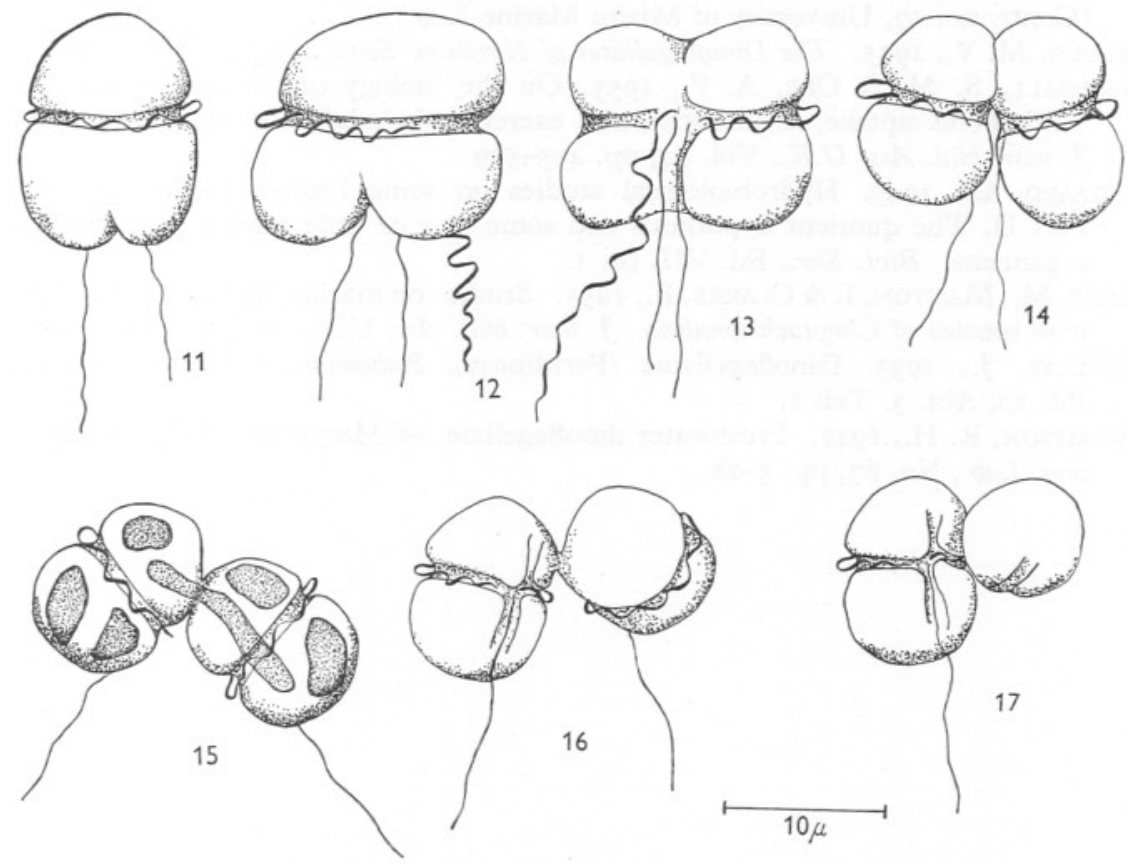

Figs. II-I7. Cell division in Gymnodinium veneficum.

Fig. II. Early stage, two longitudinal flagella and divided antapex. Fig. I2. Dorsal view, both flagella duplicated. Fig. I3. Slightly later stage than I2, ventral view. Fig. I4. Hypocones completely separate. New transverse flagellum is now in the girdle. Figs. I5-I7. Two new individuals still joined, but twisting round prior to separating. Fig. I5 shows chromatophores in a pair at this stage.

about the connecting strand until they are lying in planes at right angles (Figs. I6, I7). They then part, probably as a result of this jerky movement breaking the connecting strand.

\section{SUMMARY}

Two new species of dinoflagellate, Gymnodinium vitiligo and G. veneficum, have been described and the toxicity of G. veneficum is discussed briefly. Notes and figures on cell division in these organisms are also included. 


\section{REFERENCES}

BAINBRIDGE, R., I953. Studies on the interrelationships of zooplankton and phytoplankton. F. mar. biol. Ass. U.K., Vol. 32, pp. 385-447.

Ballantine, D. \& Morton, J. E., I956. Filtering, feeding, and digestion in the lamellibranch Lasaea rubra. F. mar. biol. Ass. U.K., Vol. 35, pp. 24I-74.

DAvIs, C. C., I948. Gymnodinium brevis sp.nov., a cause of discolored water and animal mortality in the Gulf of Mexico. Bot. Gaz., Vol. I09, pp. 358-60. (Contr. no. 17, University of Miami Marine Lab.)

Lebour, M. V., I925. The Dinoflagellates of Northern Seas, 250 pp. Plymouth.

Marshall, S. M. \& OrR, A. P., 1955. On the biology of Calanus finmarchicus. VIII. Food uptake, assimilation and excretion in adult and stage V Calanus. F. mar. biol. Ass. U.K., Vol. 34, pp. 495-529.

NyGAARD, G., 1949. Hydrobiological studies on some Danish ponds and lakes. Part II. The quotient hypothesis and some new or little known phytoplankton organisms. Biol. Skr., Bd. VII, nr. I.

Parke, M., Manton, I. \& Clarke, B., I955. Studies on marine flagellates. II. Three new species of Chrysochromulina. F. mar. biol. Ass. U.K., Vol. 34, pp. 579-609.

SCHILleR, J., 1933. Dinoflagellatae (Peridineae). Rabenhorst's Kryptogamenflora, Bd. Io, Abt. 3. Teil I.

Thompson, R. H., 1947. Freshwater dinoflagellates of Maryland. Publ. Chesapeake biol. Lab., No. 67, pp. 3-28. 